\title{
Distribution of polyprenol and dolichol in oil palms from Pisifera parents and mature plants from tissue culture propagation
}

\author{
ERKY BEBY AYU KARTIKA ${ }^{1}$, LUTHFI AZIZ MAHMUD SIREGAR ${ }^{2, \boldsymbol{v}}$, MOHAMMAD BASYUNI ${ }^{3,4}$ \\ ${ }^{1}$ Graduate Program of Agrotechnology, Faculty of Agriculture, Universitas Sumatera Utara. Jl. Prof. A. Sofyan No. 3, Medan, 20155, North Sumatra, \\ Indonesia \\ ${ }^{2}$ Department of Agrotechnology, Faculty of Agriculture, Universitas Sumatera Utara. Jl. Prof. A. Sofyan No. 3, Medan, 20155, North Sumatra, Indonesia. \\ Tel.: +62-61-8213236, Fax.: +62-61-8211924, `email: luthfi1@usu.ac.id \\ ${ }^{3}$ Department of Forestry, Faculty of Forestry, Universitas Sumatera Utara. Jl. Tri Dharma Ujung No. 1, Medan 20155, North Sumatra, Indonesia. \\ ${ }^{4}$ Mangrove and Bio-Resources Group, Center of Excellence for Natural Resources Based Technology, Universitas Sumatera Utara. Jl. Prof. A. Sofyan \\ No. 3, Medan 20155, North Sumatra, Indonesia
}

Manuscript received: 1 April. Revision accepted: 28 May 2021.

\begin{abstract}
Kartika EBA, Siregar LAM, Basyuni M. 2021. Distribution of polyprenol and dolichol in oil palms from Pisifera parents and mature plants from tissue culture propagation. Biodiversitas 22: 3423-3436. Oil palm tissue culture is carried out through indirect embryogenesis, which causes somaclonal diversity to occur at the in vitro propagation stage, especially in the callus growth phase. In the cells of all living organisms can be found a group of polyisoprenoid compounds. This study aims to determine variations in oil palm plants resulting from tissue culture based on the presence of polyisoprenoid compounds. Oil palm leaf samples (Elaeis guineensis Jacq.) were collected from the plantation of PT. Socfin Indonesia, North Sumatra, Indonesia. Sample extraction, saponification, isolation of polyisoprenoid compounds, and two-dimensional thin-layer chromatography analysis were carried out to obtain data related to total lipids, polyprenol and dolichol profile, and Carbon (C) chain length polyprenol and dolichol from oil palm leaves of Pisifera parents and their propagated derivatives by indirect embryogenesis. The results showed that the amount of polyisoprenoid mother S24 was $2.41 \mathrm{mg} / \mathrm{g}$ higher than that of the parentS8 at $2.17 \mathrm{mg} / \mathrm{g}$ dry weight. Total polyisoprenoid fromS8 plants in vitro ranged from $0.71-8.53 \mathrm{mg} / \mathrm{g}$ dry weight, with the lowest total polyisoprenoid found atS894/22 and the highest was found atS893/2. While for total polyisoprenoid from plant tissue culture of Pisifera S24 ranged from $0.73-8.05 \mathrm{mg} / \mathrm{g}$ dry weight, with the lowest total polyisoprenoid found at S24H14 and the highest was found at S24H16. The parent plants of Pisifera S8 and S24, as well as plants resulting from tissue culture, were categorized as having lipid pattern type II, which showed a balanced distribution of polyprenol with dolichol. The longest carbon chain was found in vitro plantsS8 93/4 ranged from C50-C110, while the shortest was found in plants produced in vitro S24H7 starting from C45-C55. There were variations in the carbon chain length of polyprenol and dolichol in the leaf samples derived from in vitro propagation of the Pisifera S8 and S24 parents.
\end{abstract}

Keywords: Dolichol, oil palm, polyprenol, tissue culture

\section{INTRODUCTION}

The African oil palm (Elaeis guineensis Jacq.) is a tropical plantation crop cultivated for its production of two types of vegetable oil: palm oil and palm kernel oil. It is a monocotyledonous species belonging to the family of Arecaceae, which includes more than 2,000 palm species (Hormaza et al. 2012). In recent decades, palm oil has become an important commodity as a source of world vegetable oil for many industries. For more than a decade, the palm oil sector in Indonesia has experienced massive growth, between 1990 and 2013 the area used for oil palm plantations increased tenfold from 1.1 million hectares to 10.4 million hectares with a total production of CPO (crude palm oil) 27.7 million tons of raw material, which is nearly half of global production (Yudawinata 2017).

The increasing market demand for oil palm seeds has initiated seed producers to meet the needs of oil palm seedlings through in vitro plant propagation or tissue culture approaches. Oil palm is typically propagated in vitro by indirect somatic embryogenesis, a process in which somatic cells from selected explants are induced to differentiate into somatic embryos through an intermediate phase, namely callus formation. The existence of oil palms that do not have axillary shoots, making it impossible for vegetative propagation to be done by micro cuttings (Jayanthi et al. 2011). The embryogenic callus structure is extensively propagated to increase the efficiency of somatic embryos, but this stage risks increasing the frequency of somaclonal variations (Rival et al. 2013). Somaclonal variation is defined as the genetic diversity of plants produced through the cell and plant tissue culture, both from somatic cells such as leaves, roots and stems as well as gamete cells (Neumann et al. 2017).

Plants that are produced from somaclonal variations in vitro can change their properties differ from the original plant, either permanently or temporarily. Temporary changes in traits result from epigenetic or physiological influences and are not heritable and can return to the original plant characteristics (Kaeppler et al. 2000; Miguel and Marum 2011). Meanwhile, permanent change in the traits was defined as somaclonal diversity that can be inherited and express the diversity that is owned by early plants, even giving rise to new diversity caused by 
unexplained genetic mechanisms (Smulders and De Klerk 2011; Mgbeze and Iserhienrhien 2014).

One of the secondary metabolites that are abundant in oil palm is a polyisoprenoid alcohol compound. Polyisoprenoids are metabolites that play a role in plant defense systems against biotic and abiotic stresses (Basyuni et al. 2017a; Baczewska et al. 2014). Two main groups of polyisoprenoids are polyprenol and dolichol that can be distinguished by the presence of an unsaturated (polyprenol) or saturated (dolichol) $\alpha$-isoprene subunit (Basyuni et al. 2016; Chang et al. 2015; Surmacz and Swiezewska 2011). Polyprenol typically ranges in size from C45-C60as shorter polyprenol, medium (C65-C85), and longer polyprenol (C90-C140). Dolichol is present in nearly all plant tissues, particularly in the roots (Basyuni et al. 2016, 2017a, b, 2018a), from the shorter (C25-C40), medium-chain (C65-C85), and longer chain length (C90C140). In Arifiyanto et al. (2017) research, the length of the polyisoprenoid carbon chain in oil palms varies according to each tissue or organ even though it is in the same species but comes from different growth phases and the type of fruit produced.

Several studies have been reported that the profile and occurrence of polyisoprenoids can be used as chemotaxonomic markers (Basyuni et al. 2016, 2017b, 2018b; Arifiyanto et al. 2017). The results of this study explain the differences in expression on the type, content, and carbon chain length of the polyisoprenoid from each individual in vitro culture as an indicator of somaclonal variation. Furthermore, this study made it possible to classify individuals in one stable clone from the same parent, in vitro stages and in the same culture environment. Therefore, this study aims to analyze the presence of somaclonal variations that apply to oil palm individuals resulting from tissue culture based on the presence of polyisoprenoid compounds used as chemotaxonomic markers.

\section{MATERIALS AND METHODS}

\section{Study area}

The plant material was collected from two plantation locations of PT. Socfin Indonesia, namely two samples of leaves of Pisifera parents (S8 and S24) obtained from Kebun Dolok Masihul, Serdang Bedagai District, North Sumatra, Indonesia; and 30 (thirty) leaf samples respectively from in vitro propagation of theS8 and S24 parents were obtained from Aek Loba Plantation, Asahan District, North Sumatra, Indonesia, in February 2020. Extraction and analysis of polyisoprenoid content were carried out at the Forestry Biotechnology Laboratory, Faculty of Forestry, University of North Sumatra, Medan, in March-December 2020.

\section{Chemicals}

The dolichol (C90-C105) and polyprenol ( $\left.\mathrm{C}_{90}-\mathrm{C}_{100}\right)$ standards were used as previously reported (Basyuni et al. 2016, 2017a) to identify the pattern of polyisoprenoid alcohol in the plant materials. The solvents and chemicals used, such as chloroform, methanol, ethanol, hexane, toluene, ethyl acetate, $\mathrm{KOH}$ are chemicals with analytical grade quality $\left(\right.$ Merck $^{\circledR}$ ). For the separation of chemical compounds are used Silica gel 60 TLC plate and RP-18 reverse-phase silica HPTLC plate $\left(\right.$ Merck $\left.^{\circledR}\right)$.

\section{Isolation of polyprenol and dolichol}

The isolation of polyprenol and dolichol compounds was carried out as described previously in Basyuni et al. (2016, 2017a, c) and Arifiyanto et al. (2017). Oil palm leaf samples for each number were dried at $60-75^{\circ} \mathrm{C}$ for 3 days. The dried leaf samples were crushed into a fine powder using a mill. For each sample, individual numbers were weighed as much as $5 \mathrm{~g}$ and immersed in chloroform/methanol (2:1), then incubated in a water bath for 48 hours. Furthermore, the extract was filtered to produce a supernatant using filter paper No. 2 (Advantec ${ }^{\circledR}$ ). The supernatant was dried using a rotary evaporator to produce dry fat. Then weighed to obtain lipid weight and lipid percentage to dry weight of leaf samples $\left(\mathrm{mg} \mathrm{g}^{-1}\right)$.

For all individual numbers of samples, the saponification of dry lipid extract was carried out in $86 \%$ ethanol solvent containing $2 \mathrm{M} \mathrm{KOH}$, at $65{ }^{\circ} \mathrm{C}$ for 24 hours. The unsaponified lipids are evaporated and redissolved in the hexane solvent. Then a two-dimensional thin-layer chromatography (TLC) analysis was performed using $100 \mathrm{mg}$ of the sample for each number (Basyuni et al. 2018a; 2019).

The first dimensional TLC was carried out on a silica gel glass $(20 \times 3 \mathrm{~cm})$ using toluene: ethyl acetate $(9: 1)$ developing solvent for 45 minutes (Basyuni et al. 2016). The longitudinal edge of the first dimensional TLC and the concentration zone of reverse phase TLC C-18 are connected by a magnetic bar clamp. The silica gel glass and C-18 of TLC plate were then developed in acetone for about 30 minutes to transfer all compounds that have been separated in the first dimension into the concentration zone of the reverse-phase TLC plate. Polyprenol and dolichol standards were also developed on silica gel glass and C-18 of TLC plates along with the sample lines using the development solvent system described previously. The use of this standard aims to confirm the presence of both compounds and also to determine the polyprenol and dolichol pattern from each sample analyzed based on the length of the carbon (C) chain in the detected compound. The presence of polyisoprenoid alcohol in the sample is characterized by the appearance of spots on the C18 of TLC plates developed with a solvent system and can be seen with iodine vapor. The results of this 2D-TLC chromatography can be scanned using the Canon G2000. The polyisoprenoid pattern of the sample was determined by comparing dolichol or/and polyprenol standards on TLC plates.

A standard curve constructed from the authentic standard dolichol and polyprenol is used to determine the content of the polyisoprenoid family in samples via correlation of mobility on TLC using iodine staining detection in the second-dimensional phase. Dolichol and polyprenol content in the sample was determined using ImageJ ver. 1.46r (Schneider et al. 1992), was further 
compared with the standard curves (dolichol and standard polyprenol) drawn previously.

\section{Cluster analysis}

Cluster analysis was performed on a selected subset of data from the carbon chain length of polyisoprenoids, together with the polyprenol and dolichol content (24 variables) of the leaves of theS8 and S24 Pisifera samples (parents), and 30 (thirty) leaf samples of propagated plants in vitro of the Pisifera S8 and S24 respectively. The data obtained was transformed in $\log$ (10) form as previously reported (Basyuni et al. 2018b). Dendrogram representing carbon chain length data for all samples drawn by clustering analysis using the Un-weighted Pair Group Method with Arithmetic mean (UPGMA) in MVSP (Multivariate Statistical Package) 3.22 Software (Kovach Computing Service). Euclidean distance is set as an indicator for the combination of the cluster.

\section{RESULTS AND DISCUSSION}

\section{Polyisoprenoid in Pisifera parent oil palm at PT Socfin Indonesia, Dolok Masihul Estate}

Based on the results of extraction, saponification, and analysis of polyisoprenoid content using two-dimensional Thin Layer Chromatography (TLC) on the parent plants of Pisifera S8 and S24 oil palms in Kebun Dolok Masihul PT. Socfin Indonesia shows a different quantity for each metabolite content analyzed in Table 1. Leaf samples from parentS8 showed lower total lipid $\left(7.40 \mathrm{mg} \mathrm{g}^{-1}\right.$ dry weight $)$ and polyprenol content $\left(0.67 \mathrm{mg} \mathrm{g}^{-1}\right)$ than parent S24 $(8.90$ $\mathrm{mg} \mathrm{\textrm {g } ^ { - 1 }}$ dry weight for total lipid, and $1.45 \mathrm{mg} \mathrm{g}^{-1}$ polyprenol). However, for dolichol content, theS8 parents showed a higher content $\left(1.5 \mathrm{mg} \mathrm{g}^{-1}\right)$ compared to the $\mathrm{S} 24$ parents $\left(0.95 \mathrm{mg} \mathrm{g}^{-1}\right)$. The largest number of polyisoprenoid was found in the S24 leaf sample of $2.41 \mathrm{mg} \mathrm{g}^{-1}$ dry weight while the smallest number of polyisoprenoid was in theS8 leaf sample of $2.17 \mathrm{mg} \mathrm{g}^{-1}$ dry weight.

Table 1. Total lipid, polyprenol, and dolichol profile in leaves of the parent plants of Pisifera S8 and S24 oil palms

\begin{tabular}{|c|c|c|c|c|c|c|c|c|c|c|}
\hline \multirow[t]{2}{*}{ Elder } & \multirow{2}{*}{$\begin{array}{c}\mathrm{TL} \\
\left(\mathrm{mg} \mathrm{g}^{-1} \mathrm{dw}\right)\end{array}$} & \multirow{2}{*}{$\begin{array}{c}P I \\
\left(\mathrm{mg} \mathrm{g}^{-1} \mathrm{dw}\right)\end{array}$} & \multirow{2}{*}{$\begin{array}{c}\text { Pol } \\
\left(\mathrm{mg} \mathrm{g}^{-1}\right)\end{array}$} & \multirow{2}{*}{$\begin{array}{c}\text { Dol } \\
\left(\mathrm{mg} \mathrm{g}^{-1}\right)\end{array}$} & \multicolumn{3}{|c|}{$\%$ in Total lipid } & \multicolumn{2}{|c|}{$\%$ in polyisoprenoid } & \multirow[t]{2}{*}{ Type } \\
\hline & & & & & PI & PoL & Dol & Pol & Dol & \\
\hline S8 & 7.40 & 2.17 & 0.67 & 1.50 & 29.32 & 9.05 & 20.27 & 30.88 & 69.12 & II \\
\hline S24 & 8.90 & 2.41 & 1.45 & 0.95 & 27.08 & 16.29 & 10.67 & 60.17 & 39.42 & II \\
\hline
\end{tabular}

Note; TL: total lipid, PI: polyisoprenoids, Pol: polyprenol, Dol: dolichol, dw: dry weight

Table 2. Total lipid, polyprenol, and dolichol profile in the leaves of oil palm plants as a result of tissue culture propagation from Pisifera S8

\begin{tabular}{|c|c|c|c|c|c|c|c|c|c|c|}
\hline \multirow{2}{*}{$\begin{array}{c}\text { No. } \\
\text { individual }\end{array}$} & \multirow{2}{*}{$\begin{array}{c}\text { TL } \\
\left(\mathrm{mg} \mathrm{g}^{-1} \mathbf{d w}\right)\end{array}$} & \multirow{2}{*}{$\begin{array}{c}\text { PI } \\
\left(\mathrm{mg} \mathrm{g}^{1} \mathrm{dw}\right)\end{array}$} & \multirow{2}{*}{$\begin{array}{c}\text { Pol } \\
\left(\mathrm{mg} \mathrm{g}^{-1}\right)\end{array}$} & \multirow{2}{*}{$\begin{array}{c}\text { Dol } \\
\left(\mathrm{mg} \mathrm{g}^{-1}\right)\end{array}$} & \multicolumn{3}{|c|}{$\%$ in Total lipid } & \multicolumn{2}{|c|}{$\%$ in Polyisoprenoid } & \multirow[t]{2}{*}{ Type } \\
\hline & & & & & PI & Pol & Dol & Pol & Dol & \\
\hline S8 93/1 & 61.00 & 7.92 & 4.42 & 3.50 & 12.99 & 7.26 & 5.74 & 55.83 & 44.16 & II \\
\hline S8 93/2 & 58.70 & 8.53 & 5.00 & 3.52 & 14.53 & 8.53 & 6.00 & 58.71 & 41.28 & II \\
\hline S8 93/3 & 91.60 & 7.81 & 4.28 & 3.52 & 8.53 & 4.68 & 3.85 & 54.89 & 45.10 & II \\
\hline S8 93/4 & 47.50 & 2.92 & 1.90 & 1.01 & 6.16 & 4.02 & 2.14 & 65.25 & 34.74 & II \\
\hline S8 93/5 & 56.20 & 1.95 & 0.97 & 0.97 & 3.47 & 1.74 & 1.73 & 50.09 & 49.90 & II \\
\hline S8 93/6 & 74.90 & 2.63 & 1.14 & 1.48 & 3.51 & 1.53 & 1.98 & 43.56 & 56.43 & II \\
\hline S8 93/7 & 53.60 & 3.88 & 2.12 & 1.75 & 7.24 & 3.97 & 3.27 & 54.81 & 45.18 & II \\
\hline S8 93/8 & 60.70 & 2.21 & 0.96 & 1.25 & 3.66 & 1.59 & 2.06 & 43.62 & 56.37 & II \\
\hline S8 93/9 & 42.30 & 3.25 & 1.82 & 1.43 & 7.69 & 4.31 & 3.38 & 56.01 & 43.98 & II \\
\hline S8 93/10 & 74.50 & 1.54 & 0.49 & 1.04 & 2.06 & 6.60 & 1.40 & 32.01 & 67.98 & II \\
\hline S8 93/11 & 54.40 & 8.32 & 4.39 & 3.92 & 1.53 & 8.09 & 7.22 & 52.83 & 47.16 & II \\
\hline S8 93/12 & 58.00 & 2.94 & 1.47 & 1.44 & 5.07 & 2.55 & 2.49 & 50.29 & 49.10 & II \\
\hline S8 93/13 & 73.90 & 3.00 & 1.06 & 1.93 & 4.06 & 1.45 & 2.62 & 35.56 & 64.43 & II \\
\hline S8 93/14 & 62.00 & 1.89 & 1.35 & 0.53 & 3.06 & 2.19 & 8.71 & 71.55 & 28.44 & II \\
\hline S8 93/15 & 56.60 & 3.57 & 1.91 & 1.65 & 6.32 & 3.39 & 2.93 & 53.63 & 46.36 & II \\
\hline S8 93/16 & 72.80 & 3.14 & 1.70 & 1.44 & 4.32 & 2.33 & 1.98 & 54.09 & 45.90 & II \\
\hline S8 93/17 & 61.70 & 1.71 & 0.90 & 0.81 & 2.78 & 1.46 & 1.32 & 52.60 & 47.39 & II \\
\hline S8 93/18 & 58.70 & 3.48 & 1.96 & 1.52 & 5.94 & 3.35 & 2.59 & 56.37 & 43.62 & II \\
\hline S8 93/19 & 63.30 & 1.82 & 0.61 & 1.21 & 2.88 & 9.67 & 1.91 & 33.57 & 66.42 & II \\
\hline S8 93/20 & 46.30 & 1.93 & 0.65 & 1.28 & 4.18 & 1.40 & 2.77 & 33.68 & 66.31 & II \\
\hline S8 94/11 & 64.40 & 3.42 & 1.79 & 1.63 & 5.32 & 2.79 & 2.54 & 52.43 & 47.56 & II \\
\hline S8 94/12 & 68.80 & 4.30 & 2.31 & 1.98 & 6.26 & 3.36 & 2.89 & 53.77 & 46.22 & II \\
\hline S8 94/14 & 59.40 & 2.61 & 1.13 & 1.46 & 4.39 & 1.91 & 2.47 & 43.59 & 56.40 & II \\
\hline S8 94/15 & 99.60 & 2.29 & 0.72 & 1.56 & 2.31 & 7.31 & 1.58 & 31.68 & 68.31 & II \\
\hline S8 94/16 & 54.80 & 1.29 & 0.46 & 0.82 & 2.36 & 8.52 & 1.51 & 36.08 & 63.91 & II \\
\hline S8 94/17 & 76.30 & 1.37 & 0.81 & 0.55 & 1.79 & 1.07 & 7.24 & 59.67 & 40.32 & II \\
\hline S8 94/18 & 54.40 & 2.29 & 1.10 & 1.18 & 4.22 & 2.04 & 2.18 & 48.36 & 51.63 & II \\
\hline S8 94/20 & 30.80 & 7.28 & 4.11 & 3.17 & 23.65 & 13.35 & 10.30 & 56.46 & 43.53 & II \\
\hline S8 94/21 & 56.30 & 2.94 & 1.99 & 0.93 & 5.22 & 3.55 & 1.66 & 68.08 & 31.91 & II \\
\hline S8 94/22 & 51.50 & 0.71 & 0.18 & 0.53 & 1.38 & 3.46 & 1.04 & 25.03 & 74.96 & II \\
\hline
\end{tabular}

Note; TL: total lipid, PI: polyisoprenoids, Pol: polyprenol, Dol: dolichol, dw: dry weight 
Table 3. Total lipid, polyprenol, and dolichol profile in the leaves of oil palm plants as a result of tissue culture propagation from Pisifera S24

\begin{tabular}{|c|c|c|c|c|c|c|c|c|c|c|}
\hline \multirow{2}{*}{$\begin{array}{c}\text { No. } \\
\text { individual }\end{array}$} & \multirow{2}{*}{$\begin{array}{c}\mathrm{TL} \\
\left(\mathrm{mg} \mathrm{g}^{-1} \mathrm{dw}\right)\end{array}$} & \multirow{2}{*}{$\begin{array}{c}\text { PI } \\
\left(\mathrm{mg} \mathrm{g}^{-1} \mathrm{dw}\right)\end{array}$} & \multirow{2}{*}{$\begin{array}{c}\text { Pol } \\
\left(\mathrm{mg} \mathrm{g}^{-1}\right)\end{array}$} & \multirow{2}{*}{$\begin{array}{c}\text { Dol } \\
\left(\mathrm{mg} \mathrm{g}^{-1}\right)\end{array}$} & \multicolumn{3}{|c|}{$\%$ in total lipid } & \multicolumn{2}{|c|}{ \% in polyisoprenoid } & \multirow[t]{2}{*}{ Type } \\
\hline & & & & & PI & Pol & Dol & Pol & Dol & \\
\hline S24 H1 & 65.40 & 0.96 & 0.45 & 0.51 & 1.48 & 0.69 & 0.79 & 46.96 & 53.03 & II \\
\hline $\mathrm{S} 24 \mathrm{H} 2$ & 66.00 & 1.76 & 0.80 & 0.95 & 2.68 & 1.23 & 1.45 & 45.83 & 54.16 & II \\
\hline $\mathrm{S} 24 \mathrm{H} 3$ & 12.40 & 1.12 & 0.47 & 0.65 & 9.10 & 3.83 & 5.28 & 42.05 & 57.94 & II \\
\hline $\mathrm{S} 24 \mathrm{H} 4$ & 71.80 & 3.27 & 1.91 & 1.35 & 4.57 & 2.67 & 1.88 & 58.43 & 41.25 & II \\
\hline S24 H5 & 48.30 & 6.71 & 3.59 & 3.11 & 13.90 & 7.45 & 6.45 & 53.58 & 46.41 & II \\
\hline S24 H6 & 81.00 & 1.26 & 0.98 & 0.27 & 1.57 & 1.22 & 0.34 & 78.00 & 21.99 & II \\
\hline S24 H7 & 99.90 & 7.72 & 2.50 & 5.22 & 7.74 & 2.50 & 5.23 & 32.34 & 67.65 & II \\
\hline S24 H8 & 16.00 & 2.11 & 0.79 & 1.31 & 13.19 & 4.99 & 8.20 & 37.82 & 62.17 & II \\
\hline S24 H9 & 60.90 & 1.73 & 0.81 & 0.91 & 2.85 & 1.34 & 1.51 & 47.13 & 52.86 & II \\
\hline $\mathrm{S} 24 \mathrm{H} 10$ & 65.70 & 4.48 & 2.42 & 2.06 & 6.83 & 3.69 & 3.15 & 53.97 & 46.02 & II \\
\hline S24 H11 & 32.10 & 1.54 & 1.11 & 0.42 & 4.80 & 3.46 & 1.34 & 72.10 & 27.89 & II \\
\hline S24 H12 & 90.00 & 1.56 & 0.61 & 0.95 & 1.74 & 6.78 & 1.06 & 38.94 & 61.05 & II \\
\hline S24 H14 & 32.10 & 0.73 & 0.51 & 0.22 & 2.28 & 1.59 & 0.69 & 69.78 & 30.21 & II \\
\hline S24 H15 & 58.40 & 1.38 & 0.70 & 0.68 & 2.37 & 1.20 & 1.17 & 50.60 & 49.39 & II \\
\hline S24 H16 & 114.80 & 8.05 & 3.26 & 4.79 & 7.02 & 2.84 & 4.17 & 40.51 & 59.48 & II \\
\hline S24 H17 & 41.80 & 1.43 & 0.57 & 0.86 & 3.43 & 1.37 & 2.06 & 39.86 & 60.13 & II \\
\hline S24 H18 & 45.40 & 1.13 & 0.65 & 0.48 & 2.51 & 1.44 & 1.07 & 57.32 & 42.67 & II \\
\hline S24 H19 & 71.70 & 2.27 & 0.98 & 1.29 & 3.17 & 1.37 & 1.80 & 43.14 & 56.85 & II \\
\hline S24 H20 & 14.00 & 1.25 & 0.41 & 0.83 & 8.95 & 2.99 & 5.96 & 33.37 & 66.62 & II \\
\hline $\mathrm{S} 24 \mathrm{H} 21$ & 139.00 & 3.45 & 1.63 & 1.81 & 2.48 & 1.18 & 1.31 & 47.32 & 52.67 & II \\
\hline $\mathrm{S} 24 \mathrm{H} 22$ & 74.80 & 3.48 & 1.86 & 1.61 & 4.66 & 2.50 & 2.17 & 53.57 & 46.42 & II \\
\hline $\mathrm{S} 24 \mathrm{H} 23$ & 45.20 & 1.60 & 0.65 & 0.94 & 3.54 & 1.45 & 2.09 & 40.87 & 59.12 & II \\
\hline $\mathrm{S} 24 \mathrm{H} 24$ & 68.80 & 1.64 & 0.69 & 0.94 & 2.38 & 1.02 & 1.37 & 42.65 & 57.34 & II \\
\hline $\mathrm{S} 24 \mathrm{H} 25$ & 74.10 & 1.38 & 0.64 & 0.74 & 1.87 & 0.88 & 0.99 & 46.69 & 53.30 & II \\
\hline S24 H26 & 113.00 & 1.63 & 0.86 & 0.76 & 1.45 & 0.77 & 0.68 & 53.09 & 46.90 & II \\
\hline $\mathrm{S} 24 \mathrm{H} 27$ & 64.30 & 2.45 & 1.13 & 1.32 & 3.82 & 1.76 & 2.06 & 46.05 & 53.94 & II \\
\hline $\mathrm{S} 24 \mathrm{H} 28$ & 82.90 & 0.95 & 0.36 & 0.58 & 1.15 & 0.45 & 0.71 & 38.67 & 61.32 & II \\
\hline $\mathrm{S} 24 \mathrm{H} 29$ & 60.30 & 2.58 & 2.12 & 0.45 & 4.28 & 3.52 & 0.76 & 82.22 & 17.77 & II \\
\hline S24 H30 & 173.1 & 1.71 & 1.03 & 0.68 & 0.99 & 0.60 & 0.39 & 60.39 & 39.60 & II \\
\hline S24 H31 & 65.00 & 1.71 & 1.13 & 0.58 & 2.64 & 1.74 & 0.90 & 65.96 & 34.03 & II \\
\hline
\end{tabular}

Note; TL: total lipid, PI: polyisoprenoids, Pol: polyprenol, Dol: dolichol, dw: dry weight

The composition of polyprenol and dolichol is divided into three types, namely types I, II, and III (Basyuni 2016). Type I, if there is more than $90 \%$ dominance of dolichol; Type II, shows a balanced distribution of polyprenol with dolichol; Type III, the dominance of polyprenol compounds is $90 \%$ in plant tissue. Leaf samples from the Pisifera mother tree found at PT. Socfin Indonesia is classified as type II. The results of previous studies also indicated that leaf samples from sprouts and adult plants of Tenera (Afriyanto et al. 2017), as well as leaf and mesocarp samples from 90 tested progeny (Habsyah et al. 2021), were included in the polyisoprenoid type II distribution. This type of pattern becomes a chemotaxonomic marker for oil palm plants in agro-climatic conditions similar to the location of the research activity.

\section{Polyisoprenoids from tissue culture plants in Aek Loba Estate}

Analysis of polyisoprenoid leaf samples from tissue culture plants sourced from Pisifera S8 and S24 parents Aek Loba Garden showed a varied distribution of polyprenol and dolichol. Table 2 and Table 3 showed the distribution of polyprenol and dolichol in the in vitro yield plants of Pisifera S8 and S24 parents, respectively.
Total lipids in the in vitro propagation results of Pisifera $\mathrm{S} 8$ derivatives ranged from $30.80-99.60 \mathrm{mg} \mathrm{g}^{-1}$ dry weight with the lowest total lipids found inS8 94/20 and the highest total lipids found in cultivarS8 94/15. Meanwhile, the total lipids found in vitro propagation plants results derived from Pisifera S24 ranged from 12.40 - $173.1 \mathrm{mg} \mathrm{g}^{-1}$ dry weight with the lowest total lipids in cultivar S24H3 and the highest total lipids in cultivar S24H30. For polyisoprenoid values in theS8 plants ranged from 0.71 $8.53 \mathrm{mg} \mathrm{g}^{-1}$ dry weight was found inS8 94/22 and S8 93/2, while for polyisoprenoids in the S24 Pisifera derivatives ranged from $0.73-8.05 \mathrm{mg} \mathrm{g}^{-1}$ dry weight. Based on the data above, it can be seen that the oil palm samplings of Pisifera S8 and S24 types are type II, where the individual cultivars contain proportional amounts of polyprenol and dolichol in plant tissue (Basyuni et al. 2016). Type II in the plant tissue culture results showed similarities to the parent plant sourceS8 and S24 as a source of explants where the parent plant also contained nearly the same proportion of polyprenol and dolichol. Based on the type of composition of the polyisoprenoid content, there was no difference between parent plants and tillers, both for typeS8 and S24. 
Table 4. Carbon (C) chain length polyprenols and dolichol from oil palm leaves of two Pisifera parents at PT. Socfin Indonesia, Dolok Masihul Estate, Serdang Bedagai District, North Sumatra, Indonesia

\begin{tabular}{|c|c|c|}
\hline Elder of Pisifera & Polyprenol & Dolichol \\
\hline S8 & 758085 & 100105110 \\
\hline S24 & 4550556065 & 9095100 \\
\hline
\end{tabular}

Table 5. Carbon chain length (C) polyprenol and dolichol from the oil palm leaves propagated by tissue culture from Pisifera S8 at PT Socfin Indonesia, Kebun Aek Loba, Asahan District, North Sumatra, Indonesia

\begin{tabular}{|c|c|c|}
\hline No. individual & Polyprenol & Dolichol \\
\hline S8 93/1 & $455055606570 \quad 859095$ & $505560 \quad 80859095100$ \\
\hline S8 93/2 & $455055606570 \quad 859095$ & $505560 \quad 80859095100$ \\
\hline S8 93/3 & $455055606570 \quad 859095$ & 859095100 \\
\hline S8 93/4 & 45505560657075 & 859095100105110 \\
\hline S8 93/5 & 4550556065 & $5055 \quad 80859095$ \\
\hline S8 93/6 & 4550556065 & $50556065 \quad 80859095100105$ \\
\hline S8 93/7 & 4550556065 & $556065 \quad 859095100$ \\
\hline S8 93/8 & 4550556065 & 9095100105 \\
\hline S8 93/9 & 505560 & 5055 \\
\hline S8 93/10 & 4550556065 & 9095100105 \\
\hline S8 93/11 & 4550556065 & 859095100 \\
\hline S8 93/12 & 4550556065 & 859095100 \\
\hline S8 93/13 & 4550556065 & 859095100 \\
\hline S8 93/14 & 505560 & 859095100 \\
\hline S8 93/15 & 4550556065 & $556065 \quad 859095100$ \\
\hline S8 93/16 & 4550556065 & 9095 \\
\hline S8 93/17 & 455055606570 & 9095100105 \\
\hline S8 93/18 & 4550556065 & 859095100 \\
\hline S8 93/19 & 4550556065 & 9095100105 \\
\hline S8 93/20 & 455055606570 & 9095100 \\
\hline S8 94/11 & 4550556065 & 859095100 \\
\hline S8 94/12 & 505560 & 50556065 \\
\hline S8 94/14 & 4550556065 & $505560 \quad 859095100$ \\
\hline S8 94/15 & 5055 & 859095100 \\
\hline S8 94/16 & 4550556065 & 859095100 \\
\hline S8 94/17 & 80859095 & 9095 \\
\hline S8 94/18 & 4550556065 & 9095100105 \\
\hline S8 94/20 & 4550556065 & 859095100 \\
\hline S8 94/21 & 4550556065 & 859095 \\
\hline S8 94/22 & 45505560 & 859095100 \\
\hline
\end{tabular}

\section{Carbon chain length analysis}

Polyisoprenoid compounds from oil palm leaves which are grouped into polyprenol and dolichol can be identified and distinguished by their carbon chain length using the two-dimensional Thin Layer Chromatography Analysis method (Sagami et al. 1992, Basyuni et al. 2016). Previously, Arifiyanto et al. (2017) reported that the presence of polyprenol and dolichol in Tenera hybrid of palm oil fruit mesocarp and fruit shell from Lame.

The results of the study obtained explain that parent numbers ofS8 and S24 as the Pisifera type of oil palm plant, in the Dolok Masihul Plantation of PT Socfin Indonesia was classified as Type II, where the distribution of polyprenol and dolichol in plant tissue was almost the same proportion. The length of the polyprenol carbon chain onS8: C75 - C85, and dolichol: C75 - 110, while the carbon polyprenol chain on S24: C45- C65, and dolichol: C50 C100 (Table 4 and Figure 1). The difference in the length of the polyisoprenoids carbon chain in the two samples from the Pisifera parent was caused by several factors, including increasing plant age, salinity stress, and tissue differences (Basyuni et al. 2014). Polyisoprenoid is a secondary metabolite of the terpenoid class, a related biochemical enhancer in the plant defense system against biotic and abiotic disorders (Basyuni et al. 2019). In Arifiyanto et al. (2017), the average length of polyisoprenoid carbon varies according to their respective tissues even though they are in the same species and form certain dominant families. Dolichol act as sugar-carrying lipids in N-glycoprotein biosynthesis. Dolichol has a clear role as a lipid carrier for glycan precursors in the early stages of glycosylation of $\mathrm{N}$-linked proteins, which accumulate in the endoplasmic reticulum of all eukaryotic cells (Cantagrel and Lefeber 2011). Tateyama et al. (1999) also stated that the carbon chain length distribution of polyprenol is not necessarily the same as the chain length of carbon dolichol in the same tissue. Plant polyprenol accumulated in the chloroplast determines the fluidity of thylakoid membrane which affects the efficiency of photosynthesis (Tarik et al. 2017). 
Table 6. Carbon chain length (C) polyprenol and dolichol from oil palm leaves propagated by tissue culture from Pisifera S8 at PT Socfin Indonesia, Dolok Masihul Estate, Asahan District, North Sumatra, Indonesia

\begin{tabular}{|c|c|c|}
\hline No. individual & Polyprenol & Dolichol \\
\hline S24 H1 & 45505560 & 505560 \\
\hline $\mathrm{S} 24 \mathrm{H} 2$ & 4550556065 & 9095100 \\
\hline S24 H3 & 4550556065 & 859095100 \\
\hline S24 H4 & 455055606570 & 9095100105 \\
\hline S24 H5 & 455055606570 & 859095100 \\
\hline S24 H6 & 4550556065 & 80859095 \\
\hline $\mathrm{S} 24 \mathrm{H} 7$ & 50556065 & 455055 \\
\hline S24 H8 & 4550556065 & 9095100 \\
\hline S24 H9 & 4550556065 & 50556065 \\
\hline $\mathrm{S} 24 \mathrm{H} 10$ & 4550556065 & $505560 \quad 859095$ \\
\hline $\mathrm{S} 24 \mathrm{H} 11$ & 4550556065 & $5055 \quad 80859095$ \\
\hline S24 H12 & 4550556065 & $505560 \quad 859095100$ \\
\hline S24 H14 & 50556065 & 859095100 \\
\hline S24 H15 & 50556065 & 859095100 \\
\hline S24 H16 & $455055606570 \quad 9095$ & $45505560 \quad 859095100$ \\
\hline S24 H17 & 4550556065 & 859095100105 \\
\hline S24 H18 & 50556065 & 859095100 \\
\hline S24 H19 & 4550556065 & 9095100105 \\
\hline S24 H20 & 4550556065 & 95100105 \\
\hline $\mathrm{S} 24 \mathrm{H} 21$ & 4550556065 & 95100105 \\
\hline $\mathrm{S} 24 \mathrm{H} 22$ & 4550556065 & 859095100 \\
\hline $\mathrm{S} 24 \mathrm{H} 23$ & 4550556065 & 859095 \\
\hline $\mathrm{S} 24 \mathrm{H} 24$ & 455055606570 & 9095100105 \\
\hline $\mathrm{S} 24 \mathrm{H} 25$ & 455055606570 & 859095100105 \\
\hline S24 H26 & 455055606570 & 9095100105 \\
\hline $\mathrm{S} 24 \mathrm{H} 27$ & 455055606570 & 95100105 \\
\hline S24 H28 & 4550556065 & 9095100 \\
\hline $\mathrm{S} 24 \mathrm{H} 29$ & 4550556065 & 859095 \\
\hline $\mathrm{S} 24 \mathrm{H} 30$ & 455055606570 & $556065 \quad 9095100105$ \\
\hline S24 H31 & 4550556065 & 859095100 \\
\hline
\end{tabular}

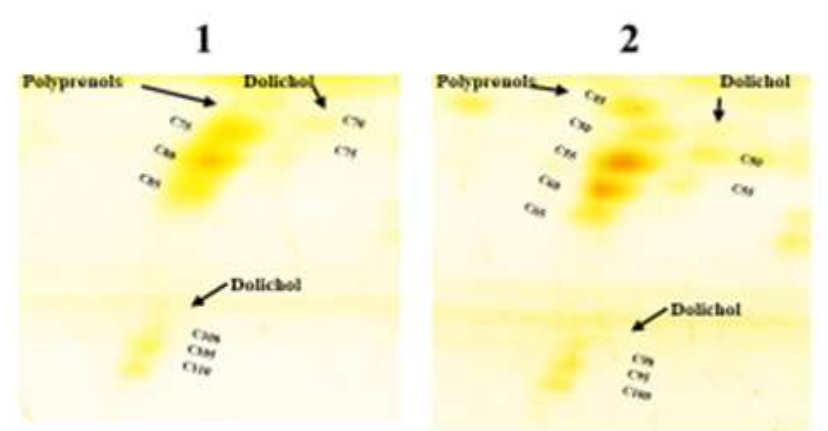

Figure 1. Two-dimensional TLC of polyisoprenoid compounds of oil palm leaf tissue of Pisifera S8 (1) and S24 (2) parents obtained from PT Socfin Indonesia, Dolok Masihul Estate, Serdang Bedagai District, North Sumatra, Indonesia

Tables 5 and 6 show that dolichol and polyprenol also dominate the polyisoprenoids in oil palm leaves produced by in vitro propagation of the Pisifera parent. The shortest carbon chain length in plant tissue culture from Pisifera S8 parent, namely for polyprenol with the carbon chain length of C50-C55 found inS8 94/15, and the longest found inS8
93/1, S8 93/2, and S8 93/3, namely C45-C95. While the shortest carbon chain length of dolichol was found in the individual number ofS8 93/9, namely C50-C55, and the longest carbon chains were obtained in the individual number ofS8 93/4, namely C50-C110 (Table 5, Figure 2 and Figure 3). The carbon chain lengths of the polyprenol and dolichol from the tissue culture propagated plants are different from their parent plants. The type of chain carbon length of polyprenol found in theS8 parents $(\mathrm{C} 75, \mathrm{C} 80$, and $\mathrm{C} 85$ ) was also found in the plant tissue culture using $\mathrm{S} 8$ as the parent, namely S8 93/1, S8 93/2, S8 93/3, S8 93/4, and S8 94/17. However, the composition of the carbon chain length of the polyprenol group of tissue culture propagation plants has a more varied composition of carbon chain lengths (between C45 - C90) for each number of individual and is not shared by the parentS8, especially the carbon chain length of the C45-C70. For the dolichol group, the individual plants from tissue culture propagation showed the type of dolichol carbon chain length that belonged to the Pisifera S8 parent, except for a few individuals who did not have the carbon chain length of parentS8, namely, S8 93/9, S8 93/16, S8 94/12, S8 94/17 and S8 94/21 (Table 5, Figures 2 and 3 ). 


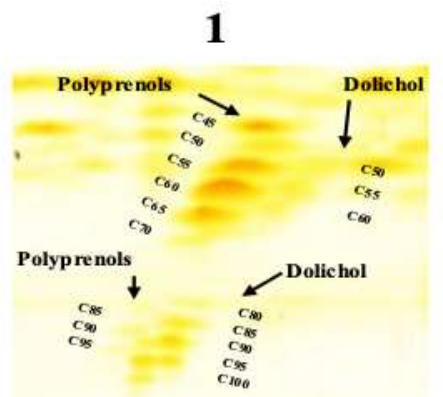

4

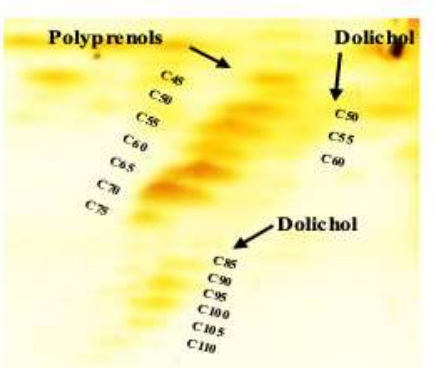

7

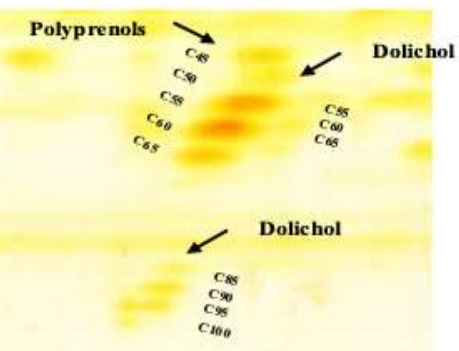

10

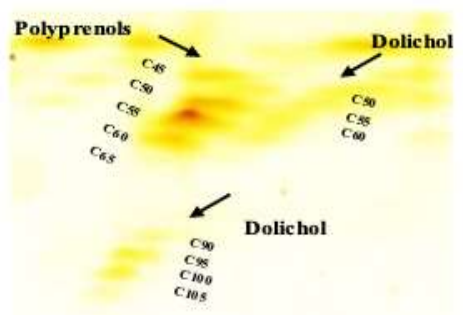

2

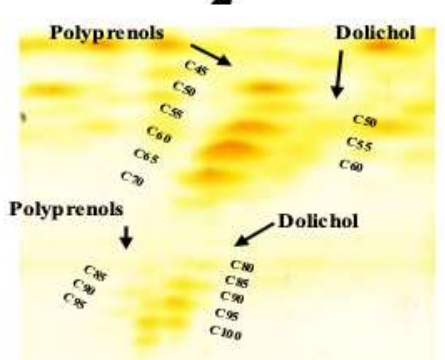

5

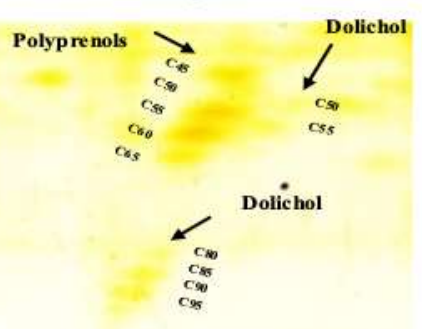

3

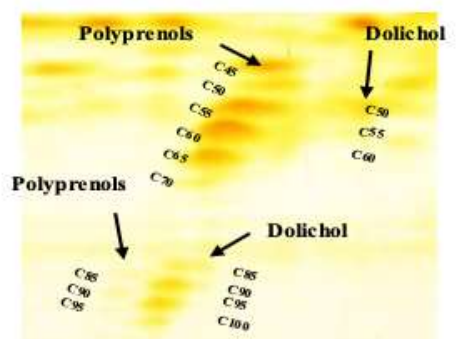

6

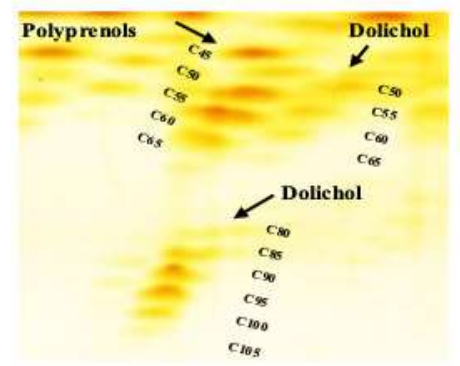

9

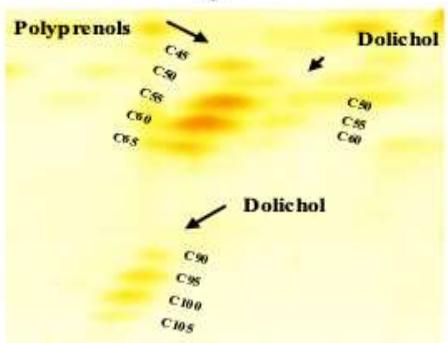

11

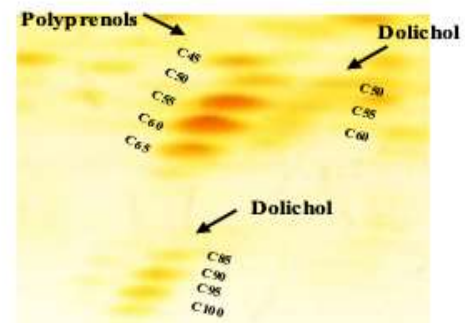

12

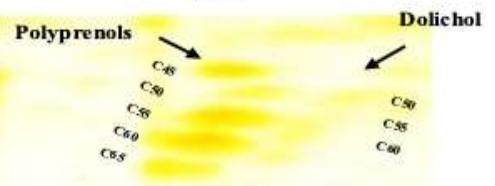

Dolichol

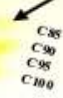

13

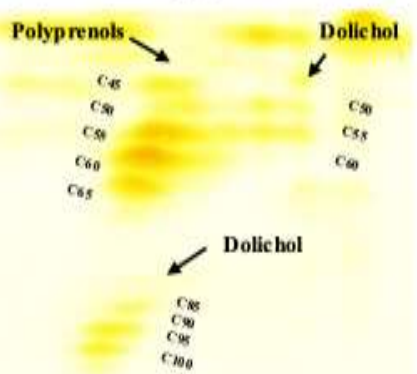

14
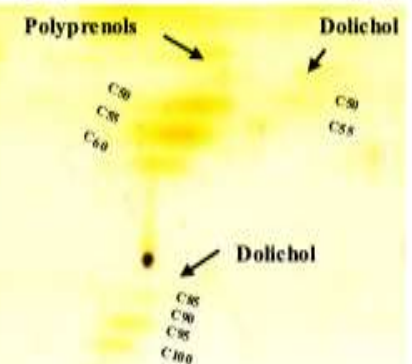

15

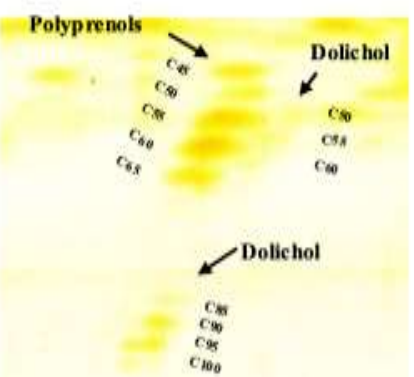

Figure 2. Two-dimensional TLC of polyisoprenoid compounds from oil palm leaf tissue derived from in vitro propagated individuals of Pisifera S8 parents obtained from PT Socfin Indonesia, Kebun Aek Loba, Asahan District, North Sumatra, Indonesia. No. Individual S8 93/1 (1), S8 93/2 (2), S8 93/3 (3), S8 93/4 (4), S8 93/5 (5), S8 93/6 (6), S8 93/7 (7), S8 93/8 (8), S8 93/9 (9), S8 93/10 (10), S8 93/11 (11), S8 93/12(12), S8 93/13 (13), S8 93/14 (14), and S8 93/15(15) 
16

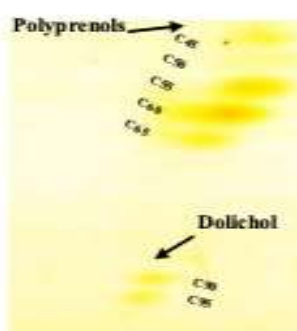

19

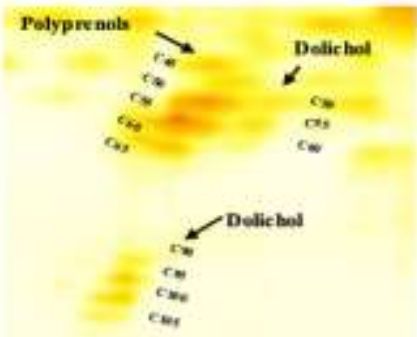

22

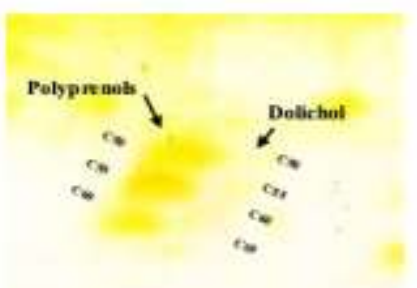

25

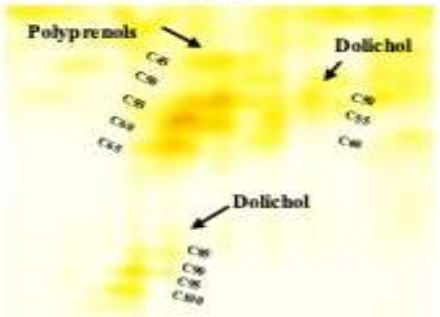

28

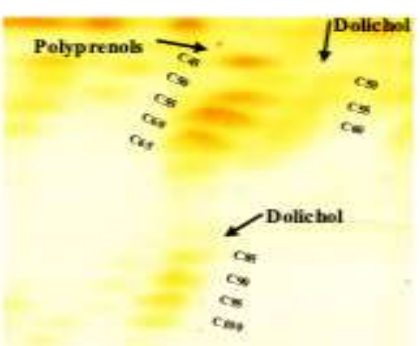

17

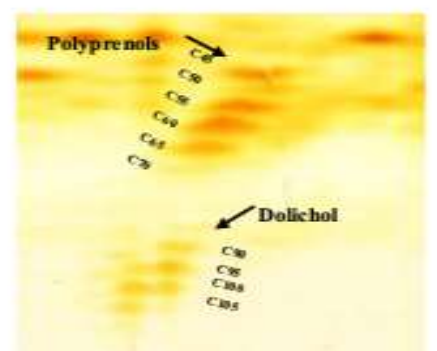

20

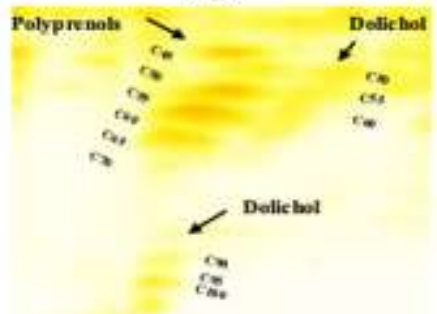

23

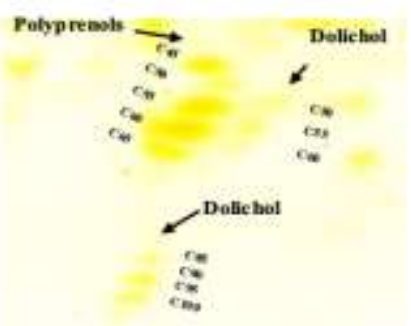

26

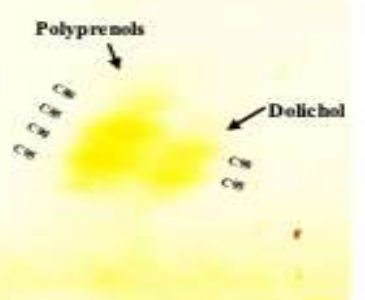

29

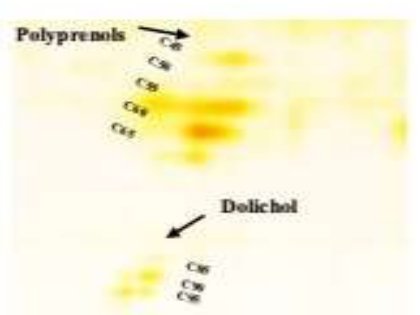

18

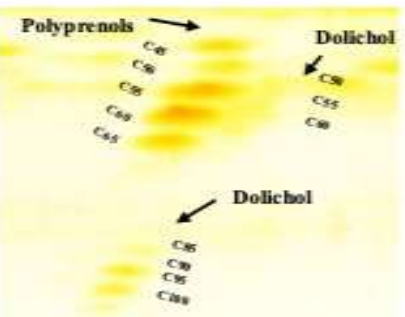

21

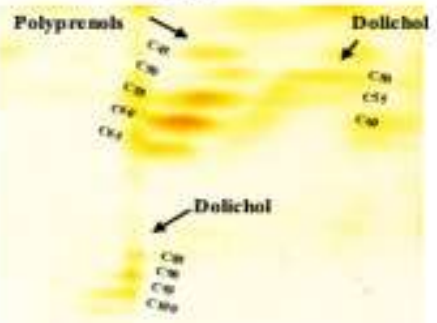

24

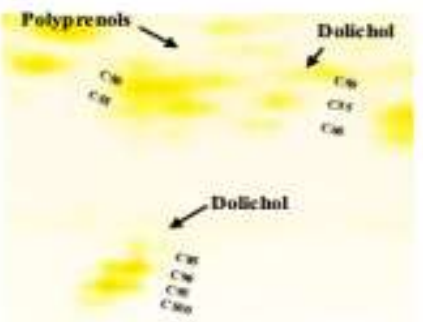

27

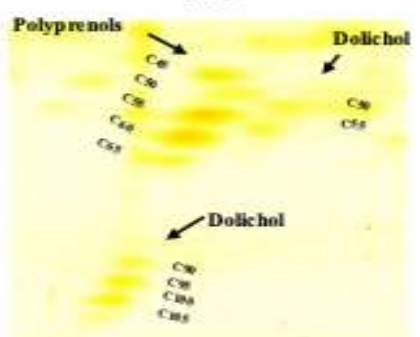

30

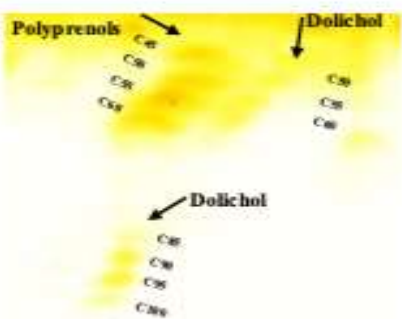

Figure 3. Two-dimensional TLC of polyisoprenoid compounds from oil palm leaf tissue derived from in vitro propagated individuals of Pisifera S8 parents obtained from PT Socfin Indonesia, Kebun Aek Loba, Asahan District, North Sumatra, Indonesia. No. IndividualS8 93/16 (16), S8 93/17(17), S8 93/18(18), S8 93/19 (19), S8 93/20 (20), S8 94/11 (21), S8 94/12 (22), S8 94/14 (23), S8 94/15 (24), S8 94/16(25), S8 94/17 (26), S8 94/18 (27), S8 94/20 (28), S8 94/21 (29), and S8 94/22 (30). 
1

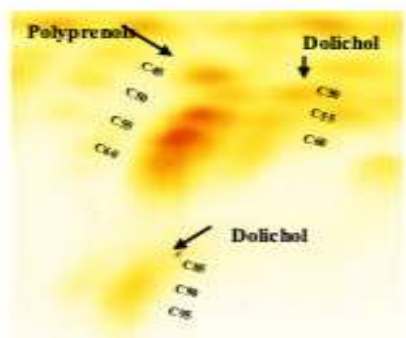

4

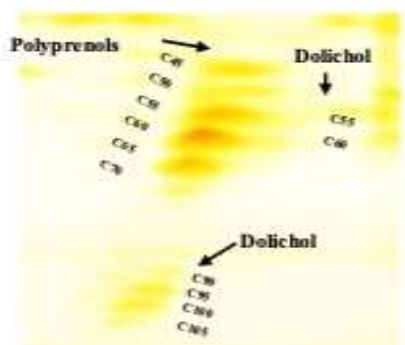

7

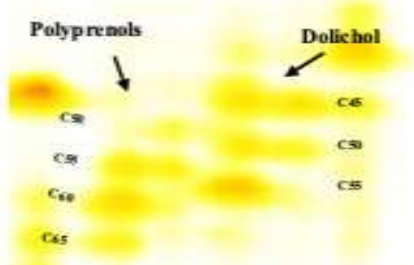

10

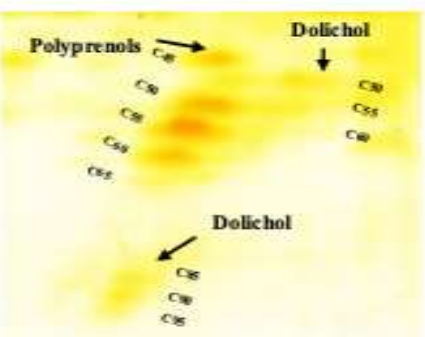

13

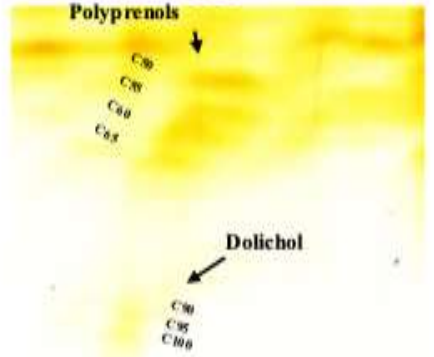

2

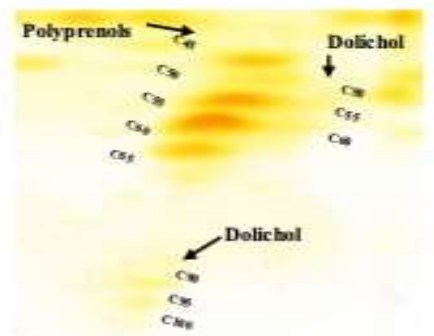

5

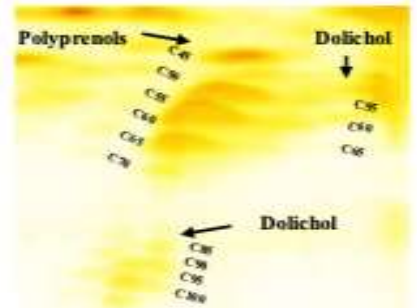

8

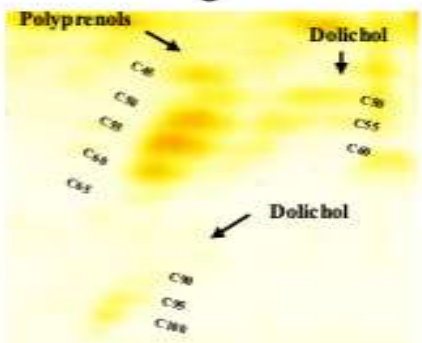

11

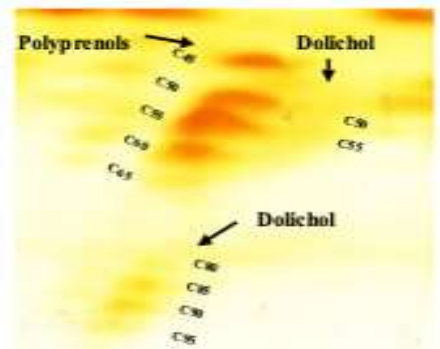

14

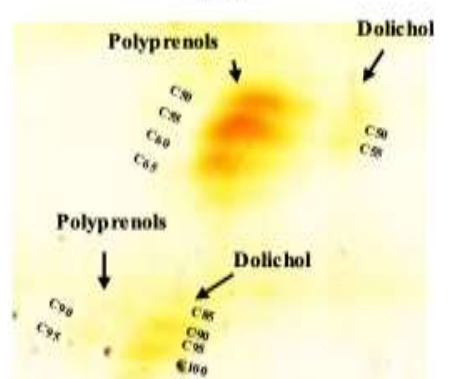

3

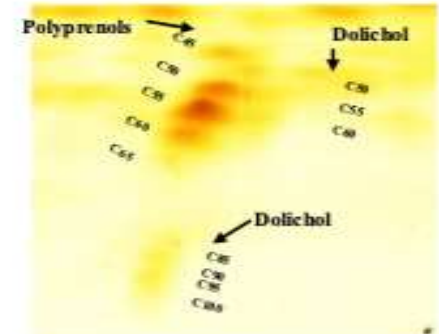

6
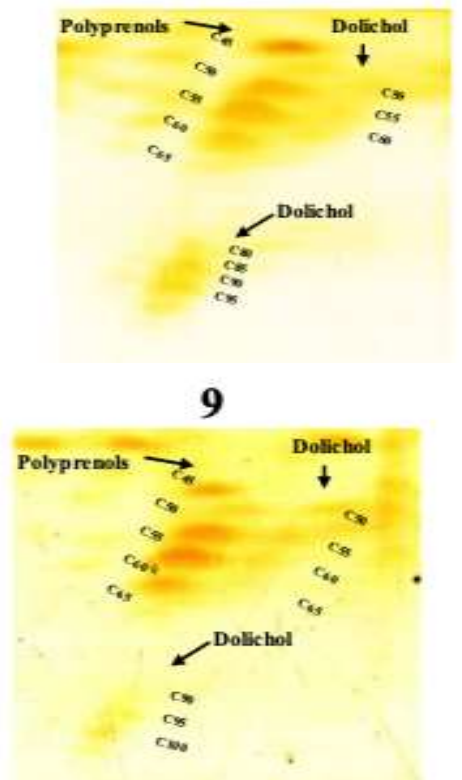

12

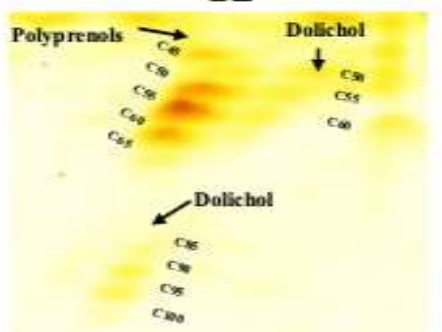

15

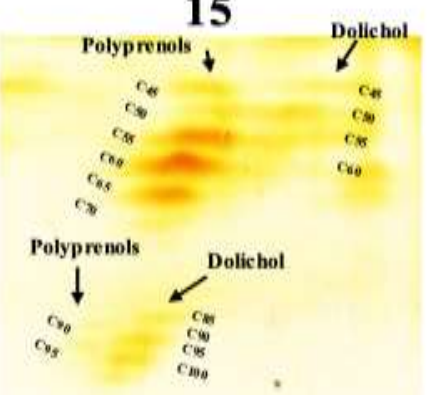

Figure 4. Two-dimensional TLC of polyisoprenoid compounds from oil palm leaf tissue derived from in vitro propagated individuals of Pisifera S24 parents obtained from PT Socfin Indonesia, Kebun Aek Loba, Asahan District, North Sumatra, Indonesia. No. Individual S24 H1 (1), S24 H2 (2), S24 H3 (3), S24 H4 (4), S24 H5 (5), S24 H6 (6), S24 H1 (7), S24 H8 (8), S24 H9 (9), S24 H10 (10), S24 H11 (11), S24 H12 (12), S24 H14 (13), S24 H15 (14), dan S24 H16 (15) 
16

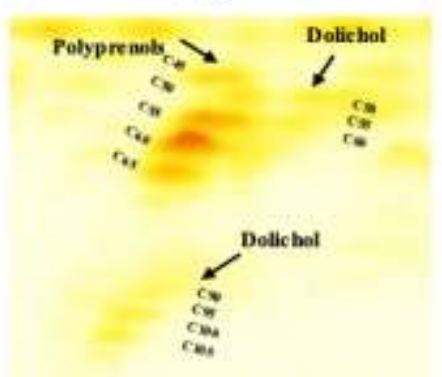

19

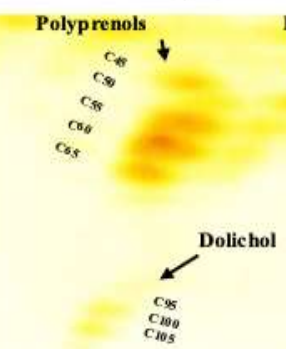

22

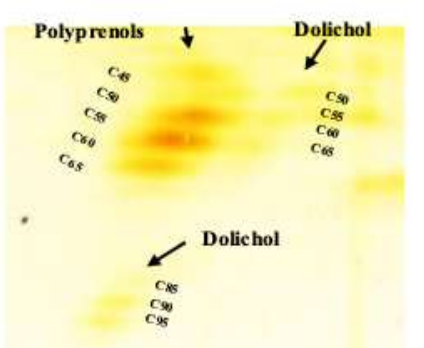

17

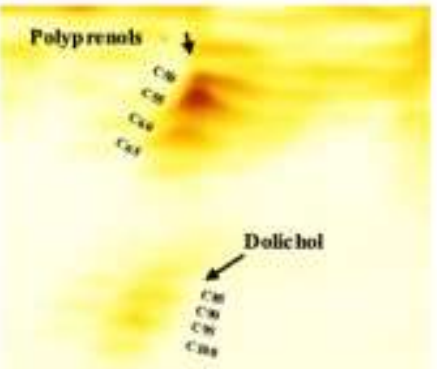

20

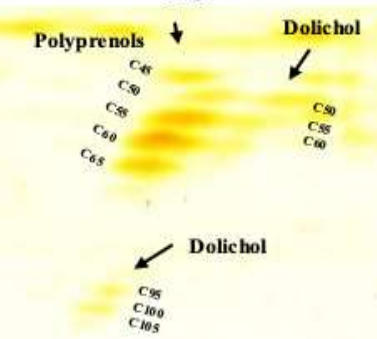

23

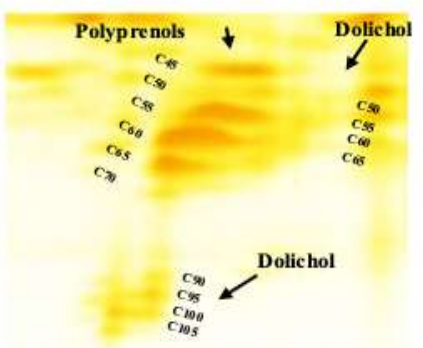

26

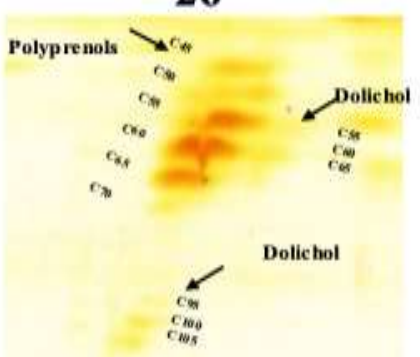

29

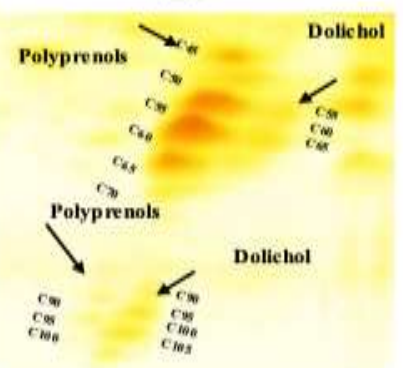

18
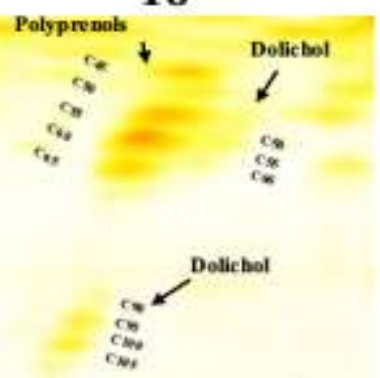

21

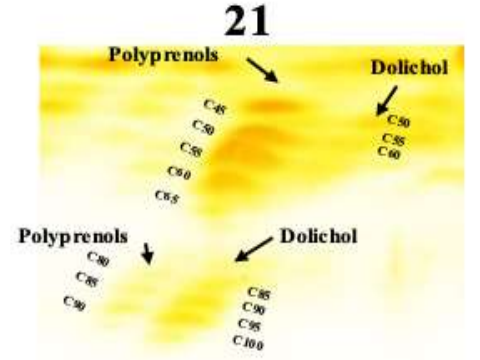

24

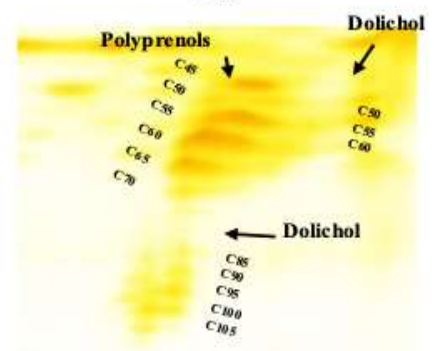

27

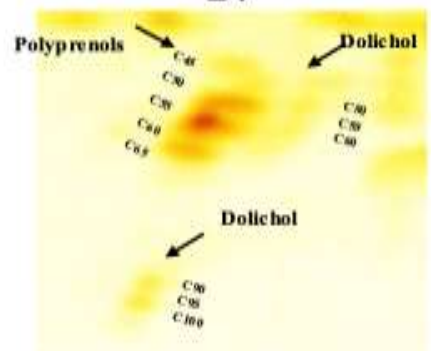

30

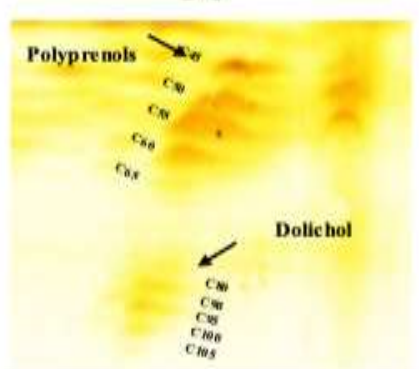

Figure 5. Two-dimensional TLC of polyisoprenoid compounds from oil palm leaf tissue derived from in vitro propagated individuals of Pisifera S24 parents obtained from PT Socfin Indonesia, Kebun Aek Loba, Asahan District, North Sumatra, Indonesia. No. Individual of S24 H17 (16), S24 H18 (17), S24 H19 (18), S24 H20 (19), S24 H21 (20), dan S24 H22 (21), S24 H23 (22), S24 H24 (23), S24 H25 (24), S24 H26 (25), S24 H27 (26), S24 H28 (27), S24 H29 (28), S24 H30 (29), S24 H31 (30). 
For samples of in vitro plant propagation from Pisifera S24 parent, the shortest polyprenol carbon chain was obtained in the individual number of S24 H1, namely C45$\mathrm{C} 60$, and the longest found in the individual number of S24 $\mathrm{H} 30$, namely C45-C100, while for the shortest dolichol obtained from an individual number of S24H7, namely C45-C55, while other individuals have the same average carbon chain, namely C50-C105 (Table 6, Figure 4 and Figure 5). For the individual numbers from the in vitro propagation of parent $\mathrm{S} 24$, all of them indicated the presence of one or more of the carbon polyprenol belonging to the parent S24 (C45, C50, C55, C60, and $\mathrm{C} 65)$, in addition to several individual clones has a carbon chain length that is not owned by the parent S24. Whereas in the plant tissue culture of the S24 parent, all of them had one or several types of carbon chain lengths that were also owned by the S24 parent, and some of the in vitro propagated individuals had the type of carbon chain lengths that the S24 parent did not (Table 6, Figure 4 and Figure 5).

Dolichol is the main polyisoprenoid compound in many flowering plants, and only a few polyprenol can be found (Sagami et al. 1992; Basyuni et al. 2017b). In the cell of eukaryotic, cis-prenyltransferases (CPTs) produce prenyl diphosphate that in some tissues is converted to dolichol due to the activity of polyprenol reductase (Cantagrel et al. 2010; Jozwiak et al. 2015) ). The prenyl diphosphate biosynthetic pathway in the eukaryotic cell requires the interaction of CPTs with an accessory CPT-binding protein for the determination of polyprenol chain length, and the examples of such complexes were found at some plants, i.e. tomato (Brasher et al. 2015), lettuce (Qu et al. 2015), Arabidopsis (Kwon et al. 2016), and guayule (Lakusta et al. 2019). The Arabidopsis genome contains nine putative cisprenyltransferase encoding genes (AtCPT1 to AtCPT9) that are expressed in a tissue-specific manner. AtCPT1, -6, and -9 are exclusively expressed in roots, and simultaneously several dolichols are identified in this tissue (Surmacz et al. 2011; Jozwiak et al. 2013).

Each plant in vitro still showed the same polyisoprenoid compound group as the Pisifera S8 and S24 parents. However, some of the in vitro propagated individuals showed the presence of polyprenol and dolichol which had different numbers and types of carbon chain lengths from theS8 and S24 parents. The question is whether the diversity of the number of carbon chain lengths possessed by individuals from tissue culture has occurred since the morphogenesis/embryogenesis process during in vitro propagation, or whether this diversity occurs after the plants are moved to the field as a result of various stresses in environmental factors that affect the expression of the presence of polyisoprenoid. Biomass from the Taxus baccata cell suspension culture showed changes in the content of isoprenoid alcohol (polyprenol with very low dolichol content) due to differences in culture age and addition of elicitor in the culture medium but did not affect the dominance of polyprenols with carbon chain lengths of $\mathrm{C} 17$ and C22. Meanwhile, in hairy root culture from Taxus media, the isoprenoid alcohol content was dominated by dolichol with carbon chain lengths $\mathrm{C} 17$ and $\mathrm{C} 22$. (Skorupinska-Tudek et al. 2007). It is noteworthy that polyprenol and dolichol level in leaves tissue of mature plant was higher than that of the seedlings. Increased polyprenol in leaves with increasing age has also been reported in Kandelia obovate and Bruguiera gymnorrhiza yellow leaf (Basyuni et al. 2016), old leaves of ginkgo and old rubber leaf (Tateyama et al. 1999), and senescing leaves (Swiezewska et al. 1994).

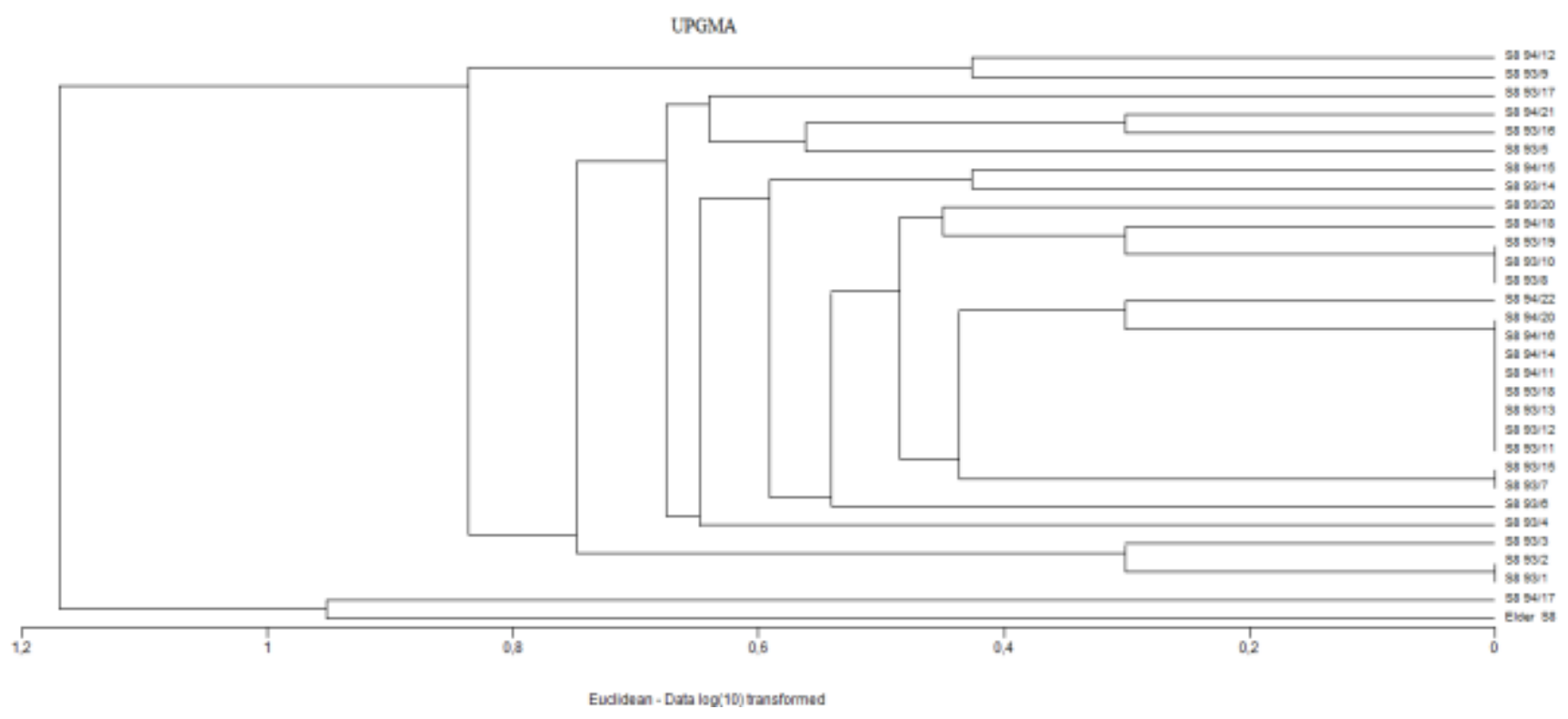

Figure 6. Dendrogram of 31 individual oil palms from Pisifera S8 parents and mature plants from tissue culture propagation based on the length of the polyisoprenoid carbon chain using $\log$ transformations (10) with Euclidean square spacing. 


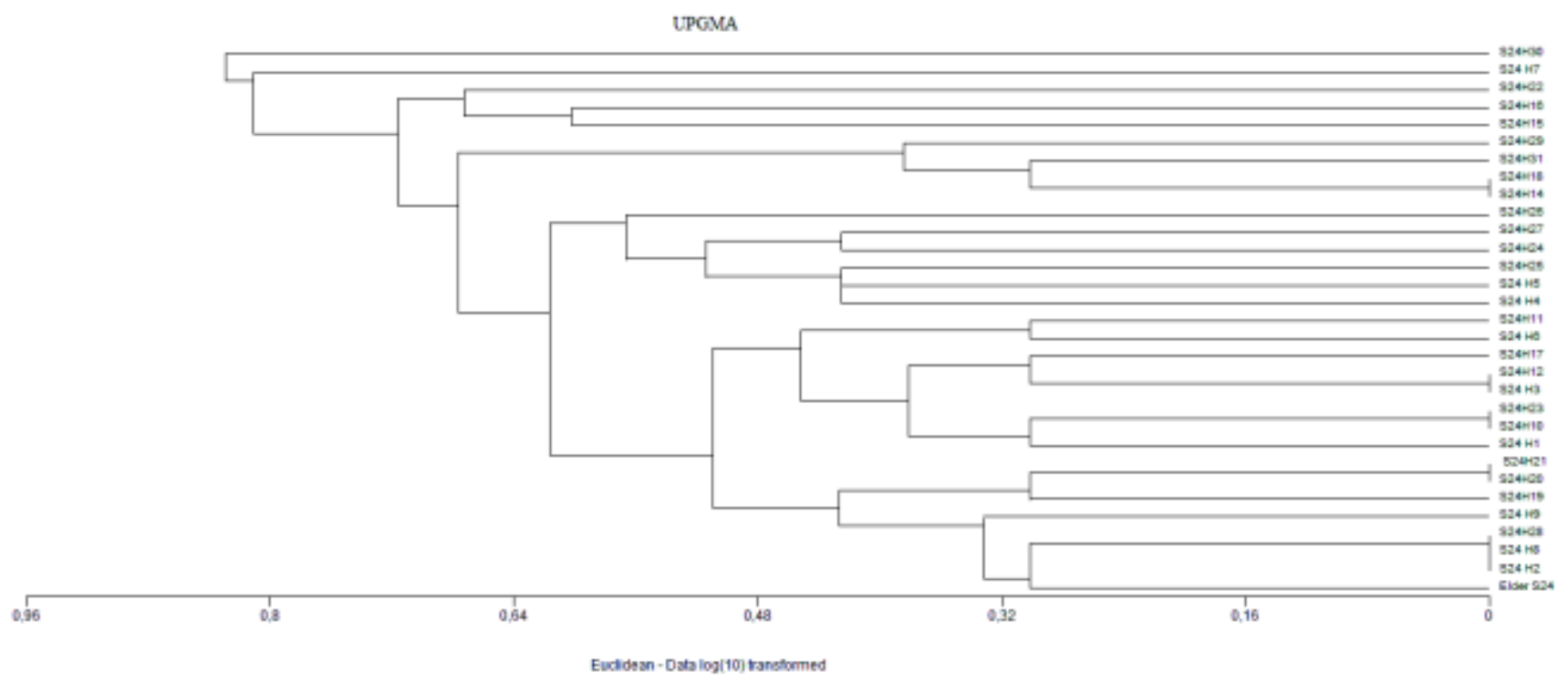

Figure 7. Dendrogram of 31 individual oil palms from Pisifera S24 parents and mature plants from tissue culture propagation based on the length of the polyisoprenoid carbon chain using log transformations (10) with Euclidean square spacing

Several studies have been reported that the profile and occurrence of polyisoprenoids can be used as chemotaxonomic markers. Polyprenols are primarily associated with photosynthetic tissues (Brasher et al. 2015; Basyuni et al. 2016, 2017a,b, 2108a,b). Polyprenol in oil palm leaf tissue occurs in length chain of C45-C65 and C90-C105, while dolichol occurs in C85-C105 (Arifiyanto 2017; Basyuni et al. 2018b). Although studies related to the biological activity of polyprenol and dolichol are still limited, in general, the results of the study explain that these two secondary metabolite compounds are involved in plant defense mechanisms against abiotic and biotic stress (Basyuni et al. 2017a; Baczewska et al. 2014). Afandi et al (2019) reported that there was a different expression of polyisoprenoid profiles concerning the level of plant resistance to Ganoderma boninense attack. This difference in expression is also related to its presence in different tissues, treatments, and tolerance levels of plants. The study also explained that the polyisoprenoid profile and polyisoprenoid carbon chain patterns in the root tissue of healthy oil palms could be distinguished from those infected with $G$. boninense. High polyprenol content (2.5 times) has been also reported on tobacco plant leaves inoculated with tobacco mosaic virus (TMV) (Bajda et al. 2009). This result reinforces the idea of polyisoprenoid involvement in plant resistance to pathogens.

\section{Cluster analysis of individuals propagated by tissue culture according to their respective parents}

The result of TLC analysis, i.e., the carbon-chain composition from 30 number individuals from in vitro propagation with Pisifera parentS8 and S24 was visualized by dendrogram using the UPGMA method. The dendrogram classifies plants into the cluster of desired traits based on the similarity of their carbon chain composition. Figure 6 showed 31 oil palm individuals propagated by tissue culture from parentS8 were grouped into two main groups based on the carbon chain of leaves tissue. The first group consists of ElderS8 and S8 94/17, linked because they both have the $\mathrm{C} 80$ and $\mathrm{C} 85$ chains in the polyprenol, and both lack the C80 and C85 chains in the dolichol compound. The second group consists of 29 individuals outside of the first group. However, based on the euclidean distance of 0.8 , the oil palm leaves were grouped into three groups: the I sub-group consisted of ElderS8 and S8 94/17. Sub-group IIA consisted ofS8 94/12 and S8 93/9 associated with the presence of C50, C55, and C60 chains in polyprenol compounds, the presence of C50 and C55 chains in their dolichol compounds, and the two individuals did not have $\mathrm{C} 80-\mathrm{C} 110$ chains in dolichol. The IIB sub-group consisted of S8 93/1, S8 93/2, S8 93/3, S8 93/4, S8 93/5, S8 93/6, S8 93/7, S8 93/8, S8 93/10, S8 93/11, S8 93/12, S8 93/13, S8 93/14, S8 93/15, S8 93/16, S8 93/17, S8 93/18, S8 93/19, S8 93/20, S8 94/11, S8 94/14, S8 94/15, S8 94/16, S8 94/18, S8 94/20, S8 94/21, and S8 94/22. Sub-group IIB is classified in one cluster due to the presence of $\mathrm{C} 45$ and $\mathrm{C} 65$ chains in polyprenol compounds in each individual.

Figure 7 showed 31 oil palm individuals propagated by tissue culture from parent S24 were grouped into three main groups based on the carbon chain of leaves tissue based on the euclidean distance of 0.8 . Group I consists only of S24 H30 because only this individual has the C100 chain on the polyprenol. Group II also consisted of only one individual, namely S24 H7, because only this individual had the $\mathrm{C} 45$ chain but did not have the C80$\mathrm{C} 105$ chain on the dolichol. Whereas Group III consisted of S24 parents along with 28 other individuals who were propagated by tissue culture from S28 parents, namely S24 H1, S24 H2, S24 H3, S24 H4, S24 H5, S24 H6, S24 H1, 
S24 H8, S24 H9, S24 H10, S24 H11, S24 H12, S24 H14, S24 H15, S24 H16, S24 H17, S24 H18, S24 H19, S24 H20, S24 H21, S24 H22, S24 H23, S24 H24, S24 H25, S24 H26, S24 H27, S24 H28, S24 H29, S24 H30, and S24 H31. Group III was grouped into one cluster with respect to the presence of C50, C5, and C60 in dolichol, except as stated from the characteristics of groups I and II.

Carbon chain lengths of dolichol and polyprenol vary from tissue to tissue within the same species and form the predominance of different families concerning growing, treating, or stressing the abiotic and biotic environments. Tateyama et al. (1999) that the distribution of long-chain polyprenol was not always the same as long-chain dolichol in the same organ. Oil palm plants that grow in different areas may differ in the length of the carbon chains of polyisoprenoid compounds (Basyuni et al. 2018b).

From the description above, it can be concluded that the oil palm leaves from in vitro propagation showed more diversity in the number and type of carbon chain lengths in the polyprenol and dolichol compounds compared to the Pisifera S8 and S24 parents. Even though the plants produced by in vitro culture have long-chain types of carbon polyprenol and dolichol which are also owned by the Pisifera S8 and S24 parents as the source of the explants. The diversity that occurs in the type and number of carbon chains that make up polyprenol and dolichol compounds in vitro propagated plants may occur due to somaclonal variations in vitro morphogenesis/ embryogenesis process or the effect of environmental factors such as abiotic or biotic stress that occurs during growth and crop development in the field.

\section{ACKNOWLEDGEMENTS}

The research was supported by the Directorate General of Research and Community Service, Ministry of Research and Technology/National Research and Innovation Agency of the Republic of Indonesia through the 2020 Master Thesis Research Scheme with a contract agreement No. 214/SP2H/AMD/LT/DRPM/2020). Thanks are conveyed to PT Socfin Indonesia for providing samples of oil palm leaves from Pisifera parents and mature plants from tissue culture propagation.

\section{REFERENCES}

Afandi D, Basyuni M, Putri LAP, Chalil D, Syahputra I. 2019. Expression of oil palm (Elaeis guineensis) polyisoprenoids in response to Ganoderma boninense infection. Biodiversitas 20 (1): 68-76. DOI: 10.13057/biodiv/d200109.

Arifiyanto D, Basyuni M, Sumardi, Putri LAP, Siregar ES, Risnasari I, Syahputra I. 2017. Occurrence and cluster analysis of palm oil (Elaeis guineensis) fruit type using two-dimensional thin-layer chromatography. Biodiversitas 18 (4): 1487-1492. DOI: 10.13057/biodiv/d180426.

Baczewska AH, Dmuchowski W, Jozwiak A, Gozdowski D, Brągoszewska P, Dąbrowski P, Swiezewska E. 2014. Effect of salt stress on prenol lipids in the leaves of Tilia 'Euchlora'. Dendrobiology 72: 177-186. DOI: 10.12657/denbio.072.015.

Bajda A, Konopka-Postupolska D, Krzymowska M, Hennig J, Skorupinska-Tudek K, Surmacz L, Wojcik J, Matysiak Z, Chojnacki
T, Skorzynska-Polit E, Drazkiewicz M, Patrzylas P, Tomaszewska M, Kania M, Swist M, Danikiewiczc W, Piotrowska W, Swiezewska E. 2009. Role of polyisoprenoids in tobacco resistance against bioticstresses. Physiol Plant 135: 351-364. DOI: 10.1111/j.13993054.2009.01204.x

Basyuni M, Putri, LAP, Nainggolan B, Sihaloho PE. 2014. Growth and biomass in response to salinity and subsequent fresh water in mangrove seedlings Avicennia marina and Rhizophora stylosa. Jurnal Managemen Hutan Tropika 20 (1): 17-25. DOI: 10.7226/jmht.20.1.17.

Basyuni M, Sagami H, Baba S, Iwasaki H, Oku H. 2016. Diversity of polyisoprenoids in ten Okinawan mangroves. Dendrobiology 75: 167175. DOI: 10.12657/denbio.075.016.

Basyuni M, Sagami H, Baba S, Putri LAP, Wati R, Oku H. 2017a. Salinity alters the polyisoprenoid alcohol content and composition of both salt-secreting and non-salt-secreting mangrove seedlings. HAYATI J Biosci 24: 206-2014. DOI: 10.1016/j.hjb.2017.11.006.

Basyuni M, Sagami H, Baba S, Iwasaki H, Oku H. 2017b. Distribution, occurrence, and cluster analysis of new polyprenyl acetones and other polyisoprenoids from North Sumatran mangroves. Dendrobiology 78 : 18-31. DOI: 10.12657/denbio.078.003.

Basyuni M, Wati R, Sagami H, Sumardi, Baba S, Oku H. 2018a. Diversity and abundance of polyisoprenoid composition in coastal plant species from North Sumatra, Indonesia. Biodiversitas 19 (1): 1-11. DOI: 10.13057/biodiv/d190101.

Basyuni M, Wati R, Deni I, Tia AR, Slamet B, Siregar ES, Syahputra I. 2018b. Cluster analysis of polyisoprenoid in oil palm (Elaeis guineensis) leaves in different land-uses to find the possible cause of yield gap from planting materials. Biodiversitas 19 (4): 1492-1501. DOI: 10.13057/biodiv/d190440.

Basyuni M, Wasilah M, Hasibuan PAZ, Sulistiyono N, Sumardi S, Bimantara Y, Hayati R, Oku H. 2019. Salinity and subsequent freshwater influences on the growth biomass and polyisoprenoids distribution of Rhizophora apiculata seedlings. Biodiversitas 20 (1): 388-395. DOI: 10.13057/biodiv/d200146.

Basyuni M. 2016. Keanekaragaman Senyawa Isoprenoid di Hutan Mangrove. USU Press, Medan. [Indonesian]

Brasher MI, Surmacz L, Leong B, Pitcher J, Swiezewska E, Pichersky E, Akhtar TA. 2015. A two-component enzyme complex is required for dolichol biosynthesis in tomato. Plant J 82 (6): 903-914. DOI: 10.1111/tpj.12859.

Cantagrel V, Lefeber DJ. 2011. From glycosylation disorders to dolichol biosynthesis defects: A new class of metabolic diseases. J Inherit Metab Dis 34: 859-867. DOI: 10.1007/s10545-011-9301-0.

Cantagrel V, Lefeber DJ, Ng BG, Guan ZQ, Silhavy JL, Bielas SL, Lehle L, Hombauer H, Adamowicz M, Swiezewska E, et al. 2010. SRD5A3 is required for converting polyprenol to dolichol and is mutated in a congenital glycosylation disorder. Cell 142 (2): 203-217. DOI: 10.1016/j.cell.2010.06.001

Chang MM, Barbara Imperiali B, Eichler J, Ziqiang Guan Z. 2015. Nlinked glycans are assembled on highly reduced dolichol phosphate carriers in the hyperthermophilic Archaea Pyrococcus furiosus. PLoS One 10 (6): e0130482. DOI: 10.1371/journal.pone.0130482.

Habsyah TS, Basyuni M, Siregar LAM, Afandi D, Syahputra I. 2021. Distribution of polyprenol and dolichol in oil palm genotype (Elaeis guineensis) involving lipase activity. Biodiversitas 22 (2): 830-837. DOI: $10.13057 /$ biodiv/d220237.

Hormaza P, Fuquen EM, Romero HM. 2012. Phenology of the oil palm interspecific hybrid Elaeis oleifera $\times$ Elaeis guineensis. Sci Agric 69: 275-280. DOI: 10.1590/S0103-90162012000400007.

Jayanthi M, Mohan NM, Mandal PK. 2011. Direct somatic embryogenesis and plantlet regeneration in oil palm. J Plant Biochem Biotechnol 20: 249-251. DOI: 10.1007/s13562-011-0053-6.

Jozwiak A, Ples M, Skorupinska-Tudek K, Kania M, Dydak M, Danikiewicz W, Swiezewska E. 2013. Sugar availability modulates polyisoprenoid and phytosterol profiles in Arabidopsis thaliana hairy root culture. Biochim Biophys Acta 1831 (2): 438-447. DOI: 10.1016/j.bbalip.2012.11.006.

Jozwiak A, Gutkowska M, Gawarecka K, Surmacz L, Buczkowska A, Lichocka M, Nowakowska J, Swiezewska E. 2015. Polyprenol reductase 2 deficiency is lethal in Arabidopsis due to male sterility. Plant Cell 27 (12): 3336-3353. DOI: 10.1105/tpc.15.00463.

Kaeppler SM, Kaeppler HF, Rhee Y. 2000. Epigenetic aspects of somaclonal variation in plants. Plant Mol Biol 43: 179-188. DOI: 10.1023/a:1006423110134. 
Kwon M, Kwon EJ, Ro DK. 2016. cis-prenyltransferase and polymer analysis from a natural rubber perspective. Methods Enzymol 576: 121-145. DOI: 10.1016/bs.mie.2016.02.026.

Lakusta AM, Kwon M, Kwon EG, Stonebloom S, Scheller HV, Ro DK. 2019. Molecular studies of the protein complexes involving cis prenyltransferase in guayule (Parthenium argentatum), an alternative rubber-producing plant. Front Plant Sci 10: 165. DOI: 10.3389/fpls.2019.00165.

Mgbeze GC, Iserhienrhien A. 2014. Somaclonal variation associated with oil palm (Elaeis guineensis Jacq.) clonal propagation: A review. Afr J Biotechnol13 (9): 989-997. DOI: 10.5897/AJBX12.011.

Miguel C, Marum L. 2011. An epigenetic view of plant cells cultured in vitro: Somaclonal variation and beyond. J Exp Bot 62 (11): 37133725. DOI: $10.1093 / \mathrm{jxb} / \mathrm{err} 155$.

Neumann H, Kumar A, Imani J. 2020. Plant Cell and Tissue Culture - A Tool in Biotechnology. Springer, Heidelberg.

Qu Y, Chakrabarty R, Tran HT, Kwon EJ, Kwon M, Nguyen TD, Ro DK. 2015. A lettuce (Lactuca sativa) homolog of human Nogo-B receptor interacts with cis-prenyltransferase and is necessary for natural rubber biosynthesis. J Biol Chem 290 (4): 1898-1914. DOI: 10.1074/jbc.M114.616920.

Rival A, Ilbert P, Labeyrie A, Torres E, Doulbeau S, Personne A. 2013. Variations in genomic DNA methylation during the long-term in vitro proliferation of oil palm embryogenic suspension cultures. Plant Cell Rep 32: 359-368. DOI: 10.1007/s00299-012-1369-y.

Skorupinska-Tudek K, Pytelewska A, Zelman-Femiak M, Mikoszewski J, Olszowska O, Gajdzis-Kuls D, Urbanska N, Syklowska-Baranek K, Hertel J, Chojnacki T, Swiezewska E. 2007. In vitro plant tissue cultures accumulate polyisoprenoid alcohols. Acta Biochim Pol 54 (4): 847-852.

Smulders MJN, De Klerk GJ. 2011. Epigenetics in plant tissue culture. Plant Growth Regul 63:137-146. DOI: 10.1007/s10725-010-9531-4.

Surmacz L, Swiezewska E. 2011. Polyisoprenoids - Secondary metabolites or physiologically important super-lipids?. Biochem Biophys Res Commun 407 (4): 627-632. DOI: 10.1016/j.bbrc.2011.03.059.

Swiezewska E, Sasak W, Mankowski T, Jankowski W, Vogtman T, Krajewska I, Hertel J, Skoczylas E, Chojnacki T. 1994. The search for plant polyprenols. Acta Biochemica Polonica 41: 221. DOI: 10.18388/abp.1994_4713.

Tateyama S, Wititsuwannakul R, Wititsuwannakul D, Sagami H, Ogura K. 1999. Dolichols of rubber plant, ginkgo and pine. Phytochem 51 (1): 11-15. DOI: 10.1016/S0031-9422(98)00581-0.

Yudawinata R. 2017. Guide to Financing Sustainable Palm Oil. Practical Guidelines for Sustainable Financing of the Palm Oil Sector. Financial Services Authority - WWF Indonesia. [Indonesian]. 